CRITICAL MEDICAL AND SURGICAL NURSING JOURNAL

Vol. 8, No. 2, Oktober 2019

Journal Homepage: https://e-journal.unair.ac.id/CMSNJ

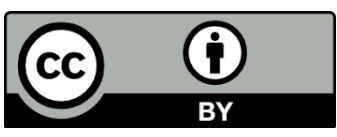

This is an Open Access article distributed under the terms of the Creative Commons Attribution 4.0 International License

\title{
Gambaran Kejadian Low Back Pain pada Pengendara Motor Ojek Online di Surabaya
}

\author{
Tintin Sukartini, Lailatun Ni'mah, Risma Wahyuningtyas
}

Fakultas Keperawatan, Universitas Airlangga, Surabaya, Indonesia

\author{
ARTICLE HISTORY \\ Diterima: 13 April 2020 \\ Disetujui: 15 Juni 2020

\section{KEYWORDS} \\ pengendara motor, sakit \\ punggung bawah

\section{CORRESPONDING AUTHOR \\ Tintin Sukartini \\ tintin-s@fkp.unair.ac.id \\ Fakultas Keperawatan, \\ Universitas Airlangga}

\begin{abstract}
Introduction: Low back pain was discomfort sensation in the lower back area or above the gluteal. Low back pain was a potential health problem for ride-hailing riders. This study aimed to describe of low back pain in online ride-hailing in Surabaya.

Method: This study was done in Surabaya, used a cross-sectional design. The sample was 100 respondents using a consecutive sampling technique. Data were obtained using a questionnaire and describe using crosstabs statistical.

Results: Online ride-hailing experienced low back pain amounts $61 \%$ and has not experienced amounts of $39 \%$. Respondents have experienced low back pain aged $>30$ years (43\%), normal BMI (41\%), work position (35\%), work duration > 8 hours per day $(50 \%)$, work period > 5 months (52\%), smoking (50\%), and not exercising (46\%).

Conclusion: Low back pain incident has a high value that amounts to $61 \%$. Online ridehailing are advised to pay attention to the duration of work and work position. Enough rest time and apply an ergonomic working position can prevent the fatigue that causes low back pain.
\end{abstract}

Sukartini, T., Ni'mah, L., \& Wahyuningtyas, R. (2019). Gambaran Kejadian Low Back Pain Pada Pengendara Motor Ojek Online di Surabaya. Crit. Méd. Surgical. Nurs. J, 8(2), 85-95.

\section{INTRODUCTION}

Ojek online sebagai salah satu inovasi pada era digital 4.0 yang menggabungkan antara kecanggihan internet dan transportasi, menjadikan ojek online pekerjaan alternatif yang mumpuni. Pengendara motor ojek online di Indonesia semakin banyak terutama di kota besar seperti Surabaya. Pekerjaan sebagai ojek online banyak menarik minat masyarakat karena jam kerja yang fleksibel, namun terdapat masalah kesehatan potensial pada pengendara motor ojek online tersebut, salah satu masalah kesehatan itu adalah low back pain. Pekerjaan sebagai ojek online memiliki risiko besar mengalami low back pain karena pekerjaan ini memiliki faktor risiko dari low back pain yaitu faktor mekanik atau kerja berlebihan. Menurut Winata, 2014 low back pain timbul dikarenakan ada pemicu yaitu kerusakan jaringan yang diakibatkan faktor mekanik (kerja berlebihan) maupun non-mekanik (peradangan), pemicu tersebut akan menimbulkan sinyal nosiceptif yang dihasilkan oleh inervasi sensorik elemen lumbal. Kerja berlebihan pada pengendara motor ojek online disebabkan karena saingan yang banyak dan tuntutan kebutuhan sehingga pengendara bekerja secara berlebihan.

Low back pain adalah sensasi ketidaknyamanan yang dirasakan di daerah punggung bawah atau di atas gluteal baik dengan penjalaran maupun tidak pada tungkai. Low back pain sangat umum pada semua populasi di dunia. Low back pain juga menjadi 
alasan yang umum terjadi disabilitas dan penurunan efektifitas kerja (Croft et al., 2018 and Kalsbeek et al., 2009). Low back pain dapat menyebabkan pembatasan aktifitas dan absen kerja atau hilang pekerjaan yang mana hal tersebut akan berpengaruh besar pada beban ekonomi individu, keluarga, industri dan bahkan pemerintah (Duthey, 2013). Kejadian low back pain sebagian besar dapat sembuh sendiri, namun terkadang ada penyebab khusus yang memerlukan penanganan medis. Low back pain akut jika tidak ditangani dengan tepat, atau jika penyebab tidak diatasi dapat menjadi low back pain kronis yang dapat menimbulkan serangan nyeri mendadak atau datang tiba-tiba, dan bisa sangat parah hingga tidak mampu bergerak atau berdiri tegak selama beberapa saat (Davies, 2007).

Global Health Matrics dalam sistematik analisis dari Global Burden Disease Study 2016 menyatakan bahwa low back pain termasuk dalam 5 kasus teratas yang menyebabkan seseorang hidup dengan keterbatasan atau disability. Analisis tersebut juga meyebutkan bahwa low back pain merupakan salah satu penyebab terbesar gangguan muskuloskeletal atau musculoskeletal disability selain neck pain (Vos et al., 2017). Angka kejadian low back pain di Indonesia sendiri masih belum diketahui secara pasti, diperkirakan $7,6 \%$ sampai $37 \%$ masyarakat mengalami low back pain (Tarwaka et al, 2004). Low back pain diderita oleh enam dari sepuluh orang setiap tahun menurut (Davies, 2007). Studi pendahuluan yang dilakukan oleh peneliti dengan wawancara kepada 10 orang pengendara motor ojek online di sekitar kampus C UNAIR Surabaya, 7 orang diantara mereka mengatakan low back pain sebagai keluhan utama, 2 orang lain mengatakan pernah mengalami low back pain meskipun bukan keluhan utama dan 1 orang mengatakan tidak pernah mengalami low back pain.

Penelitian ini bertujuan untuk mengetahui gambaran kejadian low back pain pada pengendara motor ojek online di Surabaya. Kejadian low back pain akan digambarkan dalam beberapa variabel yaitu usia, indeks massa tubuh, posisi kerja, durasi kerja, masa kerja, kebiasaan merokok dan aktifitas fisik olahraga.

\section{METHOD}

Penelitian ini menggunakan desain penelitian deskriptif dengan pendekatan cross-sectional. Kegiatan yang dilakukan adalah mengumpulkan informasi dan mendeskripsikan (memaparkan) kejadian low back pain pada pengendara motor ojek online. Penelitian ini dilakukan di Kota Surabaya khusunya di tempat-tempat ojek online berkumpul. Populasi pengendara motor ojek online di seluaruh Surabaya tidak dapat dipastikan karena dari pihak perusahaan tidak mau membuka data kepada umum, sedangkan populasi target dalam penelitian ini adalah pengendara motor ojek online di Surabaya dengan populasi terjangkau adalah pengendara motor ojek online yang sedang tidak menerima pesan antar. Penelitian ini menggunakan tehnik pengambilan sampel dengan consecutive sampling. Consecutive sampling adalah pemilihan sampel dilakukan sesuai kriteria yang ditentukan dan ditempatkan dalam kurun waktu tertentu (Nursalam, 2015). Peneliti melakukan penelitian dengan sampel sebanyak 100 orang, dengan kriteria inklusi yaitu semua pengendara motor ojek online di Surabaya dan semua pengendara motor ojek online yang sedang tidak menerima pesan antar.

Variabel dalam penelitian ini adalah low back pain, usia, IMT, posisi kerja, durasi kerja, masa kerja, kebiasaan merokok, dan aktifitas fisik olahraga. Instrumen pengumpulan data yang digunakan dalam penelitian ini berupa kuesioner sejumlah 25 pertanyaan terkait dengan data demografi, dan variabel independen. Data yang dikumpulkan diolah dengan pengkodean, tabulasi data dan entri data kemudian dilakukan penghitungan frekuensi dan crosstabs. Penelitian ini telah lulus uji etik oleh Komisi Etik Fakultas Keperawatan Universitas 
Airlangga dengan nomor sertifikat etik No. 1410KEPK/2019. Prinsip etik yang ada dalam penelitian ini menurut the Council for International Organizations of Medical Sciences (CIOMS) (The Council for International Organizations of Medical Sciences, 2016) bekerjasama dengan World Health Organization (WHO). Terdapat 8 prinsip yang digunakan dalam penelitian ini yang berasal dari 25 prinsip CIOMS.

\section{RESULT}

\section{Karakteristik Responden}

Jumlah responden dalam penelitian ini sebanyak 100 orang responden. Data umum menguraikan karakteristik demografi responden yang meliputi usia, jenis kelamin, indeks massa tubuh, riwayat kesehatan, riwayat cidera, status pekerjaan saat ini, yang diuraikan dalam tabel 1.

Tabel 1 menyajikan karakteristik demografi responden yaitu 100 orang pengendara motor ojek online di wilayah Kota Surabaya. Hasil distribusi karakteristik demografi didapatkan responden berusia diatas 30 tahun sebanyak 68 orang (68\%) dari 100 orang responden, dari segi jenis kelamin didapatkan semua responden adalah laki-laki sejumlah 100 orang (100\%), dari segi indeks massa tubuh sebanyak 68 orang (68\%) dari total 100 responden memiliki indeks massa tubuh kategori normal. Data riwayat kesehatan menunjukkan responden sebanyak 74 orang $(76,4 \%)$ tidak memiliki riwayat penyakit yang berhubungan dengan punggung bawah, dari riwayat cidera data menunjukkan mayoritas sebanyak 79 orang $(79,2 \%)$ tidak pernah atau tidak memiliki riwayat cidera punggung bawah. Data status pekerjaan saat ini menunjukkan responden yang tidak memiliki pekerjaan lain selain ojek online yang berarti ojek online merupakan pekerjaan utama dan satu-satunya yaitu sebanyak 76 orang $(77,4 \%)$ dari total 100 responden.
Gambaran Low Back Pain pada Pengendara Motor Ojek Online

Bagian ini akan menyajikan gambaran kejadian low back pain pada pengendara motor ojek online di Surabaya secara keseluruhan dan juga berdasarkan karakteristik seperti, usia, indeks massa tubuh, posisi kerja, durasi kerja, masa kerja, status merokok, aktifitas fisik olahraga. Data pada tabel 2 menunjukkan bahwa dari 100 orang responden terdapat $61 \%$ atau sebanyak 61 orang yang pernah mengalami low back pain selama menjalani profesi sebagai ojek online.

Gambaran kejadian low back pain pada pengendara motor ojek online di Surabaya berdasarkan karakteristik :

\section{Usia}

Data pada tabel 3 menunjukkan bahwa pada responden yang berusia $<30$ tahun terdapat 18 orang (18\%) yang pernah mengalami low back pain dan dari responden yang berusia $>30$ tahun terdapat 43 orang (43\%) yang pernah mengalami low back pain selama menjadi ojek online.

\section{Indeks Massa Tubuh}

Data tabel 4 menunjukkan bahwa responden dengan IMT underweight ada 7 orang (7\%) pernah mengalami low back pain, responden dengan kategori IMT normal ada 41 orang (41\%) pernah mengalami low back pain, untuk kategori overweight ada 3 orang (3\%), dari kategori pre-obes ada 8 orang (8\%), dan dari kategori obes ada 2 orang (2\%) yang pernah mengalami low back pain selama menjadi ojek online.

\section{Posisi Kerja}

Data tabel 5 menunjukkan bahwa responden dengan posisi kerja membungkuk ada 35 orang (35\%) yang mengalami low back pain dan dari responden yang memiliki posisi kerja tegak lurus ada 26 orang (26\%) yang pernah mengalami low back pain selama menjadi ojek online. 
Tabel 1. Distribusi Karakteristik Responden Pengendara Motor Ojek Online di Surabaya

\begin{tabular}{|c|c|c|c|}
\hline No & Karakteristik Demografi Responden & $\mathbf{N}$ & $\%$ \\
\hline \multirow[t]{4}{*}{1} & Usia (Tahun) & & \\
\hline & $\leq 30$ Tahun & 32 & $32 \%$ \\
\hline & $>30$ Tahun & 68 & $68 \%$ \\
\hline & Total & 100 & $100 \%$ \\
\hline \multirow[t]{4}{*}{2} & Jenis Kelamin & & \\
\hline & Laki-laki & 100 & $100 \%$ \\
\hline & Perempuan & 0 & $0 \%$ \\
\hline & Total & 100 & $100 \%$ \\
\hline \multirow[t]{7}{*}{3} & Indeks Massa Tubuh & & \\
\hline & Underweight & 10 & $10 \%$ \\
\hline & Normal & 68 & $68 \%$ \\
\hline & Overweight & 6 & $6 \%$ \\
\hline & Pre-Obes & 13 & $13 \%$ \\
\hline & Obes & 3 & $3 \%$ \\
\hline & Total & 100 & $100 \%$ \\
\hline \multirow[t]{4}{*}{4} & Riwayat Cidera & & \\
\hline & Tidak pernah cidera pada punggung & 79 & $79 \%$ \\
\hline & Pernah cidera pada punggung & 21 & $21 \%$ \\
\hline & Total & 100 & $100 \%$ \\
\hline \multirow[t]{4}{*}{5} & Riwayat Kesehatan & & \\
\hline & Tidak memiliki riwayat penyakit & 76 & $76 \%$ \\
\hline & Memiliki riwayat penyakit & 24 & $24 \%$ \\
\hline & Total & 100 & $100 \%$ \\
\hline \multirow[t]{4}{*}{6} & Status Pekerjaan Saat Ini & & \\
\hline & Tidak memiliki pekerjaan lain selain ojek online & 76 & $76 \%$ \\
\hline & Memiliki pekerjaan lain selain ojek online & 24 & $24 \%$ \\
\hline & Total & 100 & $100 \%$ \\
\hline
\end{tabular}

Tabel 2. Gambaran Low Back Pain Secara Umum Pada Pengendara Motor Ojek Online

\begin{tabular}{ccc}
\hline Riwayat mengalami Low Back Pain & $\mathbf{N}$ & $\mathbf{\%}$ \\
\hline Pernah mengalami selama menjalani profesi ini & 61 & $61 \%$ \\
Tidak pernah mengalami selama menjalani profesi ini & 39 & $39 \%$ \\
Total & $\mathbf{1 0 0}$ & $\mathbf{1 0 0 \%}$ \\
\hline
\end{tabular}

Tabel 3. Gambaran Low Back Pain Berdasarkan Usia

\begin{tabular}{|c|c|c|c|c|c|c|}
\hline \multirow{3}{*}{ Usia } & \multicolumn{4}{|c|}{ Nyeri punggung bawah } & \multirow{2}{*}{\multicolumn{2}{|c|}{ Total }} \\
\hline & \multicolumn{2}{|c|}{$\begin{array}{c}\text { Tidak pernah mengalami selama } \\
\text { menjadi ojek online }\end{array}$} & \multicolumn{2}{|c|}{$\begin{array}{l}\text { Pernah mengalami selama menjadi } \\
\text { ojek online }\end{array}$} & & \\
\hline & $\mathrm{N}$ & $\%$ & $\mathrm{~N}$ & $\%$ & $\mathrm{~N}$ & $\%$ \\
\hline$\leq 30$ tahun & 14 & $14 \%$ & 18 & $18 \%$ & 32 & $32 \%$ \\
\hline$>30$ tahun & 25 & $25 \%$ & 43 & $43 \%$ & 68 & $68 \%$ \\
\hline Total & 39 & $39 \%$ & 61 & $61 \%$ & 100 & $100 \%$ \\
\hline
\end{tabular}

\section{Durasi Kerja}

Data tabel 6 menunjukkan bahwa responden yang memiliki durasi kerja <8 jam perhari ada 11 orang (11\%) pernah mengalami low back pain dan responden dengan durasi kerja >8 jam perhari terdapat 50 orang (50\%) yang pernah mengalami low back pain selama menjadi ojek online.

\section{Masa Kerja}

Data tabel 7 menunjukkan bahwa responden yang memiliki masa kerja $<5$ bulan ada 9 orang (9\%) yang pernah mengalami low back pain, dan dari responden yang memiliki masa kerja $>5$ bulan ada 52 orang (52\%) pernah mengalami low back pain selama menjadi ojek.

\section{Status Merokok}

Data tabel 8 didapatkan bahwa dari 64 responden yang merokok, sebanyak 50 orang (50\%) pernah mengalami low back pain dan dari 36 orang responden yang tidak merokok, ada 11 orang (11\%) 
Tabel 4. Gambaran Low Back Pain Berdasarkan Indeks Massa Tubuh

\begin{tabular}{|c|c|c|c|c|c|c|}
\hline \multirow{3}{*}{ Indeks massa tubuh } & \multicolumn{4}{|c|}{ Nyeri punggung bawah } & \multirow{2}{*}{\multicolumn{2}{|c|}{ Total }} \\
\hline & \multicolumn{2}{|c|}{$\begin{array}{l}\text { Tidak pernah mengalami selama } \\
\text { menjadi ojek online }\end{array}$} & \multicolumn{2}{|c|}{$\begin{array}{l}\text { Pernah mengalami selama menjadi } \\
\text { ojek online }\end{array}$} & & \\
\hline & $\mathrm{N}$ & $\%$ & $\mathrm{~N}$ & $\%$ & $\mathrm{~N}$ & $\%$ \\
\hline Underweight & 3 & $3 \%$ & 7 & $7 \%$ & 10 & $10 \%$ \\
\hline Normal & 27 & $27 \%$ & 41 & $41 \%$ & 68 & $68 \%$ \\
\hline Overweight & 3 & $3 \%$ & 3 & $3 \%$ & 6 & $6 \%$ \\
\hline Pre-obes & 5 & $5 \%$ & 8 & $8 \%$ & 13 & $13 \%$ \\
\hline Obes & 1 & $1 \%$ & 2 & $2 \%$ & 3 & $3 \%$ \\
\hline Total & 39 & $39 \%$ & 61 & $61 \%$ & 100 & $100 \%$ \\
\hline
\end{tabular}

Tabel 5 Gambaran Low Back Pain Berdasarkan Posisi Kerja

\begin{tabular}{|c|c|c|c|c|c|c|}
\hline \multirow{3}{*}{ Posisi kerja } & \multicolumn{4}{|c|}{ Nyeri punggung bawah } & \multirow{2}{*}{\multicolumn{2}{|c|}{ Total }} \\
\hline & \multicolumn{2}{|c|}{$\begin{array}{l}\text { Tidak pernah mengalami selama } \\
\text { menjadi ojek online }\end{array}$} & \multicolumn{2}{|c|}{$\begin{array}{l}\text { Pernah mengalami selama menjadi } \\
\text { ojek online }\end{array}$} & & \\
\hline & $\mathrm{N}$ & $\%$ & $\mathrm{~N}$ & $\%$ & $\mathrm{~N}$ & $\%$ \\
\hline Membungkuk & 8 & $8 \%$ & 35 & $35 \%$ & 43 & $43 \%$ \\
\hline Tegak lurus & 31 & $31 \%$ & 26 & $26 \%$ & 57 & $57 \%$ \\
\hline Total & 39 & $39 \%$ & 61 & $61 \%$ & 100 & $100 \%$ \\
\hline
\end{tabular}

Tabel 6 Gambaran Low Back Pain Berdasarkan Durasi Kerja

\begin{tabular}{|c|c|c|c|c|c|c|}
\hline \multirow{3}{*}{ Durasi kerja } & \multicolumn{4}{|c|}{ Nyeri punggung bawah } & \multirow{2}{*}{\multicolumn{2}{|c|}{ Total }} \\
\hline & \multicolumn{2}{|c|}{$\begin{array}{c}\text { Tidak pernah mengalami selama } \\
\text { menjadi ojek online }\end{array}$} & \multicolumn{2}{|c|}{$\begin{array}{l}\text { Pernah mengalami selama menjadi } \\
\text { ojek online }\end{array}$} & & \\
\hline & $\mathrm{N}$ & $\%$ & $\mathrm{~N}$ & $\%$ & $\mathrm{~N}$ & $\%$ \\
\hline$\leq 8$ jam perhari & 28 & $28 \%$ & 11 & $11 \%$ & 39 & $39 \%$ \\
\hline$>8$ jam perhari & 11 & $11 \%$ & 50 & $50 \%$ & 61 & $61 \%$ \\
\hline Total & 39 & $39 \%$ & 61 & $61 \%$ & 100 & $100 \%$ \\
\hline
\end{tabular}

yang pernah mengalami low back pain selama menjadi ojek online.

\section{Aktifitas Fisik Olahraga}

Data Tabel 9 menunjukkan bahwa responden yang tidak berolahraga bulan ini ada 46 orang (46\%) yang pernah mengalami low back pain, dari responden yang berolahraga bulan ini ada 7 orang (7\%) yang pernah mengalami low back pain, responden yang berolahraga rutin $<3$ kali setiap minggu, ada 6 orang (6\%) dan yang $>3$ kali setiap minggu ada 2 orang (2\%) yang pernah mengalami low back pain selama menjadi ojek online..

\section{DISCUSSION}

Penelitian ini menunjukkan bahwa sebagian besar pengendara motor ojek online yaitu sebanyak 61 orang dari 100 orang responden mengaku pernah mengalami low back pain selama menjalani profesi sebagai ojek online. Responden yang terdiri dari 61 orang yang pernah mengalami low back pain ini memiliki karakteristik yang berbeda baik dari usia sampai kebiasaan dalam berolahraga yangmana sekaligu berarti bahwa dari 61 orang tersebut memiliki faktor pemicu low back pain yang berbeda. Low back pain sendiri memiliki banyak faktor pemicu yaitu dari faktor individu, faktor pekerjaan, dan faktor lingkungan fisik (Andini, 2015; Tarwaka et al, 2004; Winata, 2014).

\section{Low Back Pain Berdasarkan Usia}

Tabel 3 menunjukkan bahwa mayoritas responden yaitu 68 orang memiliki usia $>30$ tahun dan dari kategori usia tersebut mayoritas yaiutu sebanyak 43 responden pernah mengalami low back pain. Hasil yang didapatkan menunjukkan bahwa keluhan low back pain pada pengendara motor ojek online paling banyak oleh responden pada usia $>30$ tahun. Keluhan otot skeletal mulai dirasakan pada usia kerja yaitu 2565 tahun. Keluhan pertama sering muncul dan dirasakan pada usia 30 tahunan, hal tersebut sejalan dengan usia yang semakin meningkat akan terjadi 
Tabel 7 Gambaran Low Back Pain Berdasarkan Masa Kerja

\begin{tabular}{|c|c|c|c|c|c|c|}
\hline \multirow{3}{*}{ Masa kerja } & \multicolumn{4}{|c|}{ Nyeri punggung bawah } & \multirow{2}{*}{\multicolumn{2}{|c|}{ Total }} \\
\hline & \multicolumn{2}{|c|}{$\begin{array}{l}\text { Tidak pernah mengalami selama } \\
\text { menjadi ojek online }\end{array}$} & \multicolumn{2}{|c|}{$\begin{array}{l}\text { Pernah mengalami selama menjadi ojek } \\
\text { online }\end{array}$} & & \\
\hline & $\mathrm{N}$ & $\%$ & $\mathrm{~N}$ & $\%$ & $\mathrm{~N}$ & $\%$ \\
\hline$\leq 5$ bulan & 25 & $25 \%$ & 9 & $9 \%$ & 34 & $34 \%$ \\
\hline$>5$ bulan & 14 & $14 \%$ & 52 & $52 \%$ & 66 & $66 \%$ \\
\hline Total & 39 & $39 \%$ & 61 & $61 \%$ & 100 & $100 \%$ \\
\hline
\end{tabular}

Tabel 8 Gambaran Low Back Pain Berdasarkan Status Merokok

\begin{tabular}{|c|c|c|c|c|c|c|}
\hline \multirow{3}{*}{ Status merokok } & \multicolumn{4}{|c|}{ Nyeri punggung bawah } & \multirow{2}{*}{\multicolumn{2}{|c|}{ Total }} \\
\hline & \multicolumn{2}{|c|}{$\begin{array}{l}\text { Tidak pernah mengalami selama } \\
\text { menjadi ojek online }\end{array}$} & \multicolumn{2}{|c|}{$\begin{array}{l}\text { Pernah mengalami selama } \\
\text { menjadi ojek online }\end{array}$} & & \\
\hline & $\mathrm{N}$ & $\%$ & $\mathrm{~N}$ & $\%$ & $\mathrm{~N}$ & $\%$ \\
\hline Merokok & 14 & $14 \%$ & 50 & $50 \%$ & 64 & $64 \%$ \\
\hline Tidak merokok & 25 & $25 \%$ & 11 & $11 \%$ & 36 & $36 \%$ \\
\hline Total & 39 & $39 \%$ & 61 & $61 \%$ & 100 & $100 \%$ \\
\hline
\end{tabular}

Tabel 9 Gambaran Low Back Pain Berdasarkan Aktifitas Fisik Olahraga

\begin{tabular}{|c|c|c|c|c|c|c|}
\hline \multirow{3}{*}{$\begin{array}{c}\text { Aktifitas fisik } \\
\text { olahraga }\end{array}$} & \multicolumn{4}{|c|}{ Nyeri punggung bawah } & \multirow{2}{*}{\multicolumn{2}{|c|}{ Total }} \\
\hline & \multicolumn{2}{|c|}{$\begin{array}{l}\text { Tidak pernah mengalami selama } \\
\text { menjadi ojek online }\end{array}$} & \multicolumn{2}{|c|}{$\begin{array}{l}\text { Pernah mengalami selama menjadi } \\
\text { ojek online }\end{array}$} & & \\
\hline & $\mathrm{N}$ & $\%$ & $\mathrm{~N}$ & $\%$ & $\mathrm{~N}$ & $\%$ \\
\hline Tidak olahraga & 17 & $17 \%$ & 46 & $46 \%$ & 63 & $63 \%$ \\
\hline Olahraga bulan ini & 5 & $5 \%$ & 7 & $7 \%$ & 12 & $12 \%$ \\
\hline $\begin{array}{l}\text { Setiap minggu } \\
(\leq 3 \mathrm{x} / \mathrm{minggu})\end{array}$ & 10 & $10 \%$ & 6 & $6 \%$ & 16 & $16 \%$ \\
\hline Setiap minggu & 7 & $7 \%$ & 2 & $2 \%$ & 9 & $9 \%$ \\
\hline Total & 39 & $39 \%$ & 61 & $61 \%$ & 100 & $100 \%$ \\
\hline
\end{tabular}

degenerasi tulang dan keadaan ini dimulai pada usia 30 tahun dan tingkat keluhan akan semakin bertambah seiring dengan usia yang semakin bertambah. Seseorang ketika menginjak usia 30 tahun akan mulai mengalami degenerasi yang berupa kerusakan jaringan, penggantian jaringan menjadi jaringan parut, dan pengurangan cairan. Jaringan parut yang muncul akan menjadikan otot kaku dan kehilangan stabilitas pada otot serta tulang sehingga mudah merasakan nyeri pada otot maupun tulang terutama punggung yang menjadi tumpuan tubuh (Andini, 2015).

Hasil penelitian ini juga menunjukkan bahwa dari kelompok usia < 30 tahun mayoritas yaitu sebanyak 18 responden dari 32 orang juga mengalami low back pain. Hal tersebut berarti usia yang semakin tinggi tidak menjamin memiliki risiko yang lebih tinggi untuk mengalami low back pain. Secara teori nyeri pinggang atau nyeri punggung bawah dapat dialami oleh siapa saja dan pada usia berapa saja (Winata, 2014). Penelitian yang dilakukan oleh Noll, Candotti, da Rosa, \& Loss, 2016 tentang prevalensi dan faktor yang berhubungan dengan low back pain pada anak-anak dan remaja didapatkan bahwa banyak anak dan remaja mengalami low back pain, jadi risiko low back pain tidak tergantung pada usia. Low back pain dapat terjadi tergantung pada pekerjaan maupun kebiasaan seseorang. Penelitian ini memiliki karakteristik responden yang hanya berprofesi sebagai ojek online yang artinya responden ini lebih lama dalam berkendara motor ojek online untuk mencukupi kebutuhan, sehingga dari faktor tersebut responden dalam penelitian ini lebih sering terpajan faktor risiko low back pain yang lain seperti vibrasi kendaraan, posisi kerja, dan durasi kerja. Risiko low back pain dapat berkurang dengan mencegah kelelahan pada otot. Kelelahan otot dapat dicegah dengan menjaga energi di dalam otot tercukupi sehingga tidak ada 
penumpukan asam laktat yang dapat menimbulkan kelelahan otot (Andersen, 2010).

\section{Low Back Pain Berdasarkan Indeks Massa Tubuh}

Tabel 4 menunjukkan bahwa mayoritas responden yaitu sebanyak 68 orang termasuk dalam kategori indeks massa tubuh yang normal namun sebagian besar dari responden yang indeks massa tubuh normal ini mengalami low back pain, sedangkan menurut teori, peningkatan indeks massa tubuh dapat mempengaruhi low back pain, seperti pada penelitian Men et al., 2016 tentang hubungan antara obesitas dengan low back pain didapatkan bahwa obesitas memiliki hubungan dengan kejadian low back pain. Indeks massa tubuh yang berlebih dapat menjadi penyebab keluhan low back pain. Seseorang dengan indeks massa tubuh yang berlebih berisiko timbul low back pain akan lebih besar, karena beban sendi penumpu berat badan akan meningkat, sehingga dapat memungkinkan terjadinya low back pain. Penelitian oleh Sanjoy, Ahsan, Nabi, Joy, \& Hossain, 2017 tentang faktor pekerjaan dan low back pain pada perawat wanita di Bangladesh menunjukkan bahwa keluhan low back pain lebih tinggi pada kelompok responden dengan rata-rata BMI lebih tinggi dibandingkan dengan kelompok responden yang memiliki BMI lebih rendah. Indeks massa tubuh yang normal dan beban berat tubuh yang ditanggung oleh tulang belakang akan berkurang pada profesi ini yang lebih banyak duduk, sehingga beban berat tubuh pengendara motor tidak hanya ditanggung oleh tulang belakang melainkan sebagian oleh tempat duduk atau dudukan motor sehingga meskipun pengendara motor ojek online memiliki massa tubuh yang tidak normal memiliki kemungkinan untuk tidak mempunyai risiko mengalami low back pain (Amrulloh, Jayanti, Wahyuni, \& Widjasena, 2017).

\section{Low Back Pain Berdasarkan Posisi Kerja}

Tabel 5 menunjukkan bahwa sebagian besar yaitu 43 responden dalam penelitian ini memiliki posisi kerja yaitu duduk berkendara dengan posisi membungkuk dan 35 orang dari mereka mengeluhakan pernah mengalami low back pain selama menjadi ojek online. Posisi atau sikap kerja merupakan penyebab nyeri punggung bawah yang sering tidak disadari oleh penderita seperti posisi duduk yang salah dapat menimbulkan nyeri punggung bawah. Hasil penelitian yang dilakukan oleh Akinbode 0, Funmito, \& Afolabi, 2017 tentang prevalensi dan manajemen dari nyeri punggung bawah pada pengendara motor komersial di Ileas bagian barat daya Nigeria. Penelitian tersebut menyatakan bahwa posisi berkendara memiliki hubungan terhadap low back pain dengan posisi berkendara membungkuk ke depan memiliki proporsi lebih tinggi dari pada duduk berkendara dengan tegak. Pekerja yang terbiasa duduk dengan posisi punggung yang tidak tertopang pada kursi dapat menjadi penyebab keluhan nyeri punggung bawah pada profesi-profesi tertentu (Winata, 2014). Posisi kerja yang membungkuk akan memaksa tulang belakang mengarah ke depan dan menjauhi posisi anatomis tulang punggung, hal tersebut akan mempengaruhi otot-otot punggung yangmana akan tertekan dan menegang yang dapat menyebabkan kelelahan otot pungung dan keluhan low back pain pada pengendara motor.

\section{Low Back Pain Berdasarkan Durasi Kerja}

Tabel 6 menunjukkan bahwa mayoritas responden yaitu 60 orang pengendara motor ojek online memiliki durasi kerja lebih dari 8 jam setiap hari dan sebagian dari responden mengeluhkan pernah mengalami low back pain sedangkan dari responden yang bekerja kurang dari 8 jam setiap hari 28 orang dari 39 responden tidak mengalami low back pain. Penelitian ini juga sejalan dengan penelitian Wang et al., 2017 tentang kejadian low back pain pada pengemudi taxi di Cina. Penelitian tersebut juga menganalisis hubungan antara durasi kerja dengan low back pain dan menyatakan bahwa ada hubungan yang signifikan antara durasi kerja dan kejadian low back pain. Mayoritas responden pada penelitian tersebut memiliki durasi kerja yang lebih dari 8 jam 


\section{T. SUKARTINI ET AL.}

setiap hari. Peningkatan durasi kerja atau berkendara dengan waktu yang lama dapat menyebabkan kelelahan pada otot punggung bawah dan dapat menyebabkan ketegangan pada daerah lumbal yang akan mengakibatkan low back pain. Hal tersebut sejalan dengan penelitian tentang prevalensi dan faktor risiko low back pain pada pengemudi profesional di Kano, Nigeria oleh Rufa'i, Sa'idu, Ahmad, \& Elmi, 2015 yang menghubungkan antara durasi kerja dengan kejadian low back pain dan memberikan hasil bahwa kejadian low back pain terjadi pada pengemudi yang memiliki dursi kerja lebih dari 5 jam/hari. Responden pada penelitian tersebut mayoritas yaitu sebanyak 125 responden dari total 200 orang responden memiliki durasi kerja lebih dari 10 jam setiap hari. Penelitian yang dilakukan oleh Simsek, Yagci, \& Senol, 2017 tentang prevalensi dan faktor risiko low back pain pada pemberi layanan kesehatan di Denzili juga menunjukkan bahwa pekerja yang pernah mengalami low back pain memiliki rata-rata durasi kerja lebih dari 8 jam perhari. Durasi berkendara yang lama merupakan faktor risiko mayor terhadap low back pain pada pengendara. Hal tersebut berkaitan dengan potensi cidera yang dapat terjadi jika jam kerja melebihi batas, sehingga cenderung mengalami kelelahan otot dan keluhan nyeri punggung bawah. Durasi kerja yang lebih tinggi akan meningkatkan risiko terjadi low back pain. Pengendara motor ojek online seringkali memiliki durasi berkendara yang tinggi yaitu diatas 8 jam/hari. Hal tersebut dilakukan untuk mencapai target poin pendapatan tertentu, tidak sedikit pengendara motor ojek online yang beroperasi dari pukul 5 pagi sampai pukul 11 malam. Durasi lama dalam berkendara yang tidak diimbangi dengan istirahat yang cukup dapat menyebabkan kelelahan pada otot punggung, apalagi dengan posisi berkendara yang salah dan dipertahankan dalam beberapa jam akan semakin meningkatkan risiko keluhan low back pain pada pengendara motor ojek online ini.

\section{Low Back Pain Berdasarkan Masa Kerja}

Tabel 7 menunjukkan bahwa sebagian besar responden yaitu 62 orang memiliki masa kerja lebih dari 5 bulan dan sebagian dari responden dengan masa kerja lebih dari 5 bulan tersebut pernah mengalami low back pain selama menjadi ojek online. Masa kerja merupakan akumulasi aktivitas kerja seseorang yang dilakukan dalam jangka waktu yang panjang. Jika aktivitas tersebut dilakukan terusmenerus akan mengakibatkan gangguan pada tubuh. Tekanan fisik pada kurun waktu tertentu mengakibatkan kinerja otot berkurang. Tekanantekanan akan terakumulasi setiap hari pada suatu masa yang panjang, sehingga mengakibatkan kesehatan memburuk disebut juga kelelahan klinis (Koesyanto, 2013). Masa kerja yang semakin lama juga dapat menyebabkan kejenuhan pada daya tahan otot dan tulang secara fisik, yang akan berujung pada keluhan skeletal. Penelitian oleh Jia et al., 2016 tentang prevalensi dan faktor risiko low back pain pada petugas operasional ladang kincir angin menunjukkan bahwa petugas yang memiliki masa kerja lebih lama yaitu lebih dari 3 tahun memiliki total kejadian low back pain lebih banyak dibandingkan dengan petugas yang memiliki masa kerja dibawah 3 tahun. Pengendara motor ojek online lebih banyak memiliki masa kerja lebih dari 5 bulan, bahkan ada yang telah menjadi pengendara motor ojek online yang lebih dari 1,5 tahun. Masa kerja yang tinggi ditambah dengan durasi kerja yang lama perhari dan posisi berkendara yang salah dapat meningkatkan risiko keluhan low back pain pada pengendara motor ojek online.

\section{Low Back Pain Berdasarkan Status Merokok}

Tabel 8 menunjukkan bahwa mayoritas responden yaitu 64 pengendara motor ojek online memiliki status merokok sebagai perokok, dan dari jumlah responden yang merokok sebanyak 50 orang pernah mengalami low back pain selama menjadi ojek online. Hubungan merokok dengan keluhan low back pain terjadi karena korelasi yang kuat antara merokok dan 
proses degenerasi tulang (Patrianingrum, Oktaliansah, \& Surahman, 2015). Zat-zat dalam rokok seperti nikotin dan taar akan menyebabkan kemampuan tubuh dalam melakukan pertukaran oksigen dan karbon dioksida tidak maksimal. Jika pertukaran gas oksigen dan karbon dioksida terjadi tidak maksimal, hal tersebut akan menyebabkan pasokan oksigen berkurang. Oksigen yang dibutuhkan untuk membentuk energi yang digunakan saat kontraksi otot dan memecahkan asam laktat akan berkurang, sehingga otot akan cepat mengalami kelelahan karena sumber energi yang kurang dan menumpuknya asam laktat (Munir, 2012). Penelitian oleh Williams et al., 2015 tentang faktor risiko dan disabilitas berhubungan dengan low back pain pada lansia dan didapatkan orang dengan status merokok yaitu saat ini sedang menjadi perokok memiliki risiko lebih tinggi mengalami low back pain sedangkan penelitian oleh Yang \& Haldeman, 2016 tentang faktor perilaku yang berhubungan dengan low back pain pada populasi dewasa di US (United Stated) menyatakan bahwa status merokok seseorang baik itu saat ini sedang merokok maupun mantan perokok dapat berhubungan dengan kejadian low back pain. Hal tersebut diakibatkan oleh kandungan nikotin pada rokok yang dapat mengambat suplai nutrisi dan oksigen ke sel-sel tulang dan otot. Nikotin pada rokok dapat menyebabkan vasokontriksi pada pembuluh darah dan penebalan dinding pembuluh darah. Pengendara motor ojek online yang merokok akan memiliki risiko lebih tinggi mengalami low back pain dari pada pengendara motor yang tidak merokok, dan pengendara motor yang merokok dengan intensitas yang tinggi juga akan lebih berisiko tinggi mengalami low back pain dari pada yang memiliki intensitas merokok rendah. Hal tersebut dikarenakan kandungan nikotin yang bertambah banyak jika seseorang memiliki intensitas merokok yang tinggi. Pengendara motor ojek online menjadikan merokok sebagai penghilang kantuk dan pengisi waktu luang mereka selama menunggu pesanan. Sebagian dari pengendara juga mengaku merokok dapat menjadi pelampiasan saat lelah berkendara.

\section{Low Back Pain Berdasarkan Aktifitas Fisik Olahraga}

Tabel 9 menunjukkan bahwa mayoritas responden yaitu sebanyak 63 orang dari total 100 pengendara motor ojek online tidak pernah melakukan aktifitas fisik olahraga, dan 46 orang dari jumlah responden yang tidak berolahraga pernah mengalami low back pain selama menjadi ojek online. Kebugaran jasmani dan kemampuan fisik dapat dipengaruhi oleh kebiasaan olahraga, karena olahraga melatih otot sehingga keluhan otot lebih jarang terjadi. Olahraga memiliki peran penting dalam memperkuat punggung, meningkatkan kapasitas aerobik dan kebugaran jasmani secara umum. Latihan teratur juga dapat mengurangi stres pada punggung, dengan meningkatkan kekuatan dan fleksibilitas otot punggung dapat menjadi upaya preventif terhadap keluhan low back pain (Munir, 2012). Penelitian yang dilakukan oleh Carlos \& Vanderlei, 2015 tentang prevalensi dan faktor risiko yang berhubungan dengan low back pain pada orang dewasa di Kota Brazil menunjukkan bahwa tidak ada hubungan yang signifikan antara aktifitas fisik dengan kejadian low back pain. Orang yang tidak aktif secara fisik dapat memiliki kemungkinan lebih tinggi untuk mengalami low back pain, namun kausalitas terbalik dapat terjadi dalam hubungan antara aktifitas fisik dengan low back pain yaitu karena orang dengan low back pain cenderung akan melakukan olahraga sebagai pengobatan atau terapi untuk mengurangi low back pain yang dialami. Beberapa pengendara motor ojek online yang sudah melakukan aktifitas fisik olahraga namun masih mengalami low back pain, dapat diakibatkan oleh karena pengaruh intensitas merokok pengendara motor ojek online lebih besar dari pada intensitas olahraga yang dilakukan, selain itu juga dapat dimungkinkan pengendara motor ojek online tersebut melakukan aktifitas fisik olahraga 
setelah merasakan keluhan low back pain, sehingga aktifitas fisik olahraga hanya digunakan dalam pengobatan atau mengurangi keluhan. Beberapa pengendara motor ojek online yang menjadi responden mengatakan setelah menjadi ojek online mereka tidak memiliki waktu untuk berolahraga karena waktu mereka dihabiskan untuk berkendara dan beristirahat dirumah

\section{CONCLUSION}

Hasil penelitian yang dilakukan pada 100 responden pengendara motor ojek online di Surabaya di dapatkan bahwa sebagian besar pengendara motor ojek online tersebut yang mengalami low back pain memiliki riwayat usia lebih dari 30 tahun, dengan indeks massa tubuh yang normal, posisi kerja atau berkendara membungkuk, dengan durasi kerja lebih dari 8 jam perhari, memiliki masa kerja lebih dari 5 bulan sebagai ojek online, dan dengan status perokok aktif serta tidak melakukan aktifitas olahraga.

\section{REFERENCE}

Akinbode 0, O., Funmito, F., \& Afolabi, O. (2017). Prevalence and Management Practices of Low Back Pain Among Commercial Motorcyclists in Ilesa Southwest, Nigeria. Science Journal of Public Health, $5(3)$, 186. https://doi.org/10.11648/j.sjph.20170503.15

Amrulloh, F. F., Jayanti, S., Wahyuni, I., \& Widjasena, B. (2017). Faktor-Faktor yang Berhubungan dengan Keluhan Nyeri Punggung Bawah pada Sopir Bus Antar Kota Propinsi PO. Nusantara Trayek KudusJakarta. ISSN 2356-3346, 5(April), 113-120.

Andersen. (2010). Effect of Physical Exercise Interventions on Musculoskeletal Pain in All Body Regions Among Office Workers: A One-Year Randomized Controlled Trial. Manual Therapy J. Copenhagen, 15(1), 100-104. https://doi.org/10.1016/j.math.2009.08.004

Andini, F. (2015). Risk factors of low back pain in workers. J MAJORITY / Volume 4 Nomor 1, 4, 12-19.

Carlos, L., \& Vanderlei, M. (2015). Prevalence of low back pain and associated factors in adults from a middle-size Brazilian city, 1575-1582. https://doi.org/10.1590/141381232015205.02162014

Croft, P., Ferreira, M., Kongsted, A., Anema, J. R., Chou, R., Ferreira, P. H., ... Peul, W. C. (2018). What low back pain is and why we need to pay attention. The Lancet, 391(10137), 2356-2367. https://doi.org/10.1016/s0140-6736(18)30480$\mathrm{x}$

Davies, K. (2007). Buku Pintar Nyeri Tulang dan Otot. Jakarta: Penerbit Erlangga.

Duthey, B. (2013). Priority Medicines for Europe and the World "A Public Health Approach to Innovation ", (March).

Jia, N., Li, T., Hu, S., Zhu, X., Sun, K., Yi, L., ... Wang, Z. (2016). Prevalence and its risk factors for low back pain among operation and maintenance personnel in wind farms. BMC Musculoskeletal Disorders, 1-10. https://doi.org/10.1186/s12891-016-1180-y

Kalsbeek, W. D., Darter, J. D., Agans, R. P., Freburger, J. K., Holmes, G. M., Carey, T. S., ... Wallace, A. S. (2009). The Rising Prevalence of Chronic Low Back Pain. Archives of Internal Medicine, 169(3), 251. https://doi.org/10.1001/archinternmed.2008.54 3

Koesyanto, H. (2013). Masa Kerja dan Sikap Kerja Duduk Terhadap Nyeri Punggung. Issn 1858-1196, 9(1), 9-14.

Men, C. S., Chou, L., Hons, M., Brady, S. R. E., Hons, M., Hons, B., ... Wluka, A. E. (2016). The Association Between Obesity and Low Back Pain and Disability Is Affected by Mood Disorders, 95(15), 1-7. https://doi.org/10.1097/MD.000000000000336 7

Munir, S. (2012). Analisis Nyeri Punggung Bawah pada Pekerja Bagian Final Packing dan Part Supply Di PT. X Tahun 2012. Universitas Indonesia.

Noll, M., Candotti, T. C., da Rosa, B. N., \& Loss, F. J. (2016). Back pain prevalence and associated factors in children and adolescents: an epidemiological population study, 1-10. https://doi.org/10.1590/S15188787.2016050006175

Nursalam. (2015). METODOLOGI PENELITIAN ILMU KEPERAWATAN : Pendekatan Praktis. (A. Suslia \& P. P. Lestari, Eds.) (4th ed.). Jakarta: Salemba Medika.

Patrianingrum, M., Oktaliansah, E., \& Surahman, E. (2015). Prevalensi dan Faktor Risiko Nyeri Punggung Bawah di Lingkungan Kerja Anestesiologi Rumah Sakit Dr. Hasan Sadikin Bandung. Jurnal Anestesi Perioperatif, 3(1), 47-56. https://doi.org/10.15851/jap.v3n1.379

Rufa'i, A. A., Sa'idu, I. A., Ahmad, R. Y., \& Elmi, O. S. (2015). Archives of Environmental \& Occupational Health Prevalence and Risk Factors for Low Back Pain Among Prevalence and Risk Factors for Low Back Pain Among Professional Drivers in Kano , Nigeria, (August). https://doi.org/10.1080/19338244.2013.84513 9

Sanjoy, S. S., Ahsan, G. U., Nabi, H., Joy, Z. F., \& Hossain, A. (2017). Occupational factors and low back pain : a cross - sectional study of Bangladeshi female nurses. BMC Research Notes, 1-6. https://doi.org/10.1186/s13104-017-2492-1 
Simsek, S., Yagci, N., \& Senol, H. (2017). Prevalence of and risk factors for low back pain among healthcare workers in Denizli, 29(April), 71-78. https://doi.org/10.5505/agri.2017.32549

Tarwaka et al. (2004). Ergonomi untuk Keselamatan, Kesehatan Kerja dan Produktivitas (Ed 1, Cet). Surakarta - 57147: UNIBA PRESS.

The Council for International Organizations of Medical Sciences. (2016). International Ethical Guidelines for International Ethical Guidelines for. Geneva.

Vos, T., Abajobir, A. A., Abbafati, C., Abbas, K. M., Abate, K. H., Abd-Allah, F., ... Murray, C. J. L. (2017). Global, regional, and national incidence, prevalence, and years lived with disability for 328 diseases and injuries for 195 countries, 19902016: A systematic analysis for the Global Burden of Disease Study 2016. The Lancet, 390(10100), 1211-1259. https://doi.org/10.1016/S01406736(17)32154-2
Wang, M., Yu, J., Liu, N., Liu, Z., Wei, X., Yan, F., \& Yu, S. (2017). Low back pain among taxi drivers: a cross-sectional study, 67(May), 290-295. https://doi.org/10.1093/occmed/kqx041

Williams, J. S., Ng, N., Peltzer, K., Yawson, A., Biritwum, R., Maximova, T., ... Arokiasamy, P. (2015). Risk Factors and Disability Associated with Low Back Pain in Older Adults in Low- and Middle-Income Countries . Results from the WHO Study on Global AGEing and Adult Health ( SAGE ), 1-21. https://doi.org/10.1371/journal.pone.0127880

Winata, D. S. (2014). Diagnosis dan Penatalaksanaan Nyeri Punggung Bawah dari Sudut Pandang Okupasi, 20(54), 20-27.

Yang, H., \& Haldeman, S. (2016). Behavior-related Factors Associated with Low Back Pain in the US Adult Population. https://doi.org/10.1097/BRS.000000000000166 5 